ORIGINAL ARTICLE

\title{
Purification and Characterization of Peroxidase From Anthracnose Disease Infected Papaya (Carica papaya L.)
}

\author{
L Bari ${ }^{1}$, P Hassan 2 , N Absar ${ }^{3}$, S Khatun ${ }^{4}$ and M I Hossain ${ }^{5}$ \\ ${ }^{1}$ Department of Food Technology \& Nutritional Science, Mawlana Bhasani Science $\&$ Technology \\ University, Tangail; 2M olecular Biology Laboratory, Institute of Biological Science, Rajshahi \\ University, Rajshahi; ${ }^{3}$ Department of Biochemistry \& Biotechnology, University of Science \& \\ Technology, Chittagong; ${ }^{4} D$ epartment of Biochemistry \& M olecular Biology, Rajshahi U niversity, \\ Rajshahi; ${ }^{5}$ D epartment of Biotechnology \& G enetic Engineering, Mawlana Bhasani Science \& \\ Technology University, Tangail, Bangladesh
}

\begin{abstract}
Peroxidase enzyme was isolated and purified from the pulp of disease infected ripen papaya of local variety by $90 \%$ ammonium sulphate precipitation, chromatography on DEAEcellulose followed by hydrophobic chromatography on Phenyl Sepharose CL-4B and the purifications achieved was about 7.2 fold with $2.5 \%$ recovery. The purified enzyme was homogeneous as judged by polyacrylamide slab gel electrophoresis. The purified enzyme had a Mr of about 55,000 and 50000 as determined by gel filtration on Sephadex G-100 and SDS-PAGE, respectively. The molecular mass of the enzyme was found to be very similar under both reducing and non-reducing conditions indicating that the enzyme contains no subunit. The enzyme has the following characteristics: $\mathrm{pH}$ optima at 6.0 , temperature optima around $38^{\circ} \mathrm{C}$, enzyme activity was found to be strongly inhibited in the presence of potassium cyanide and $\mathrm{Fe}^{+2}$ while the activity was found to be remarkably increased in the presence of ammonium sulphate. The $\mathrm{Km}$ value for the peroxidase obtained with pyrogallol as substrate was $0.027 \mathrm{mM}$.
\end{abstract}

Key W ords: Papaya, A nthracnose disease, Peroxidase purification

\section{Introduction}

Peroxidases (E.C. 1.11.1.7, hydrogen donor oxidoreductase) utilize hydrogen peroxide or substituted peroxides for the oxidation of a large number of substrate. ${ }^{1}$ Most peroxidases are glycoproteins containing $\mathrm{N}$-linked oligosaccharide chains. $^{2}$

They are found in most cells of various tissues and organs in plants and seen to be a normal component of such cells and respond to developmental and environmental clues. ${ }^{3}$ It has been implicated in a variety of physiological processes such as ethylene biogenesis, cell development, membrane integrity, response to injury and disease resistance. ${ }^{4-7}$ The enzyme has also been involved in deteriorative changes in flavor, texture and color in raw and processed fruits and vegetables. ${ }^{8-10}$ The enzyme occurs in multiple molecular forms and is present in most fruits and vegetables in a soluble and bound (ionically and covalently) forms whose catalytic properties are influenced by growth and physiological stages. ${ }^{11-14}$

Peroxidase has wide applications in health sciences as a diagnostic tool. A uto-antibodies directed against the thyroid peroxidase are widely used to diagnose human autoimmune thyroid disease.15 A variety of enzymes including peroxidase, alkaline phosphatase, urease and Dgalactosidase etc. have been used in ELISA kits. A mong which peroxidase is widely used to prepare "antibody-enzyme" or "anti-antibody-enzyme conjugates" for ELISA due to its high turn over rate, rapid availability, ease of conjugation and better sensitivity. ${ }^{16-17}$ 
50 Bangladesh J M ed Biochem; 6(2)

We have observed that the peroxidase activity of papaya increased significantly with ripening and thereafter the activity increased further in the rotten stage. To our knowledge, data on the purification and characterization of peroxidase from rotten papaya are not available in our country. This paper describes the purification and characterization of peroxidase from rotten stage of papaya fruit infected with Colletotrichum gloeosporiodes.

\section{M aterials and M ethods}

Chemicals and gel matrices

All chemicals used were of analytical grade. DEAE-cellulose was purchased from Pharmacia Fine Chemical Co. Ltd. Upsala, Sweden. SDSPAGE chemicals were from Sigma Chemical Co. Ltd. USA. Phenyl Sepharose CL-4B was the product of Aldrich-Sigma Chemical C 0 . L td. USA and Sephadex G-100 from Sigma Chemical Co. Ltd. USA.

Plant material: Local variety of papaya containing the highest amount of peroxidase activity as reported in our study was used for enzyme purification and characterization.

Preparation of crude enzyme extract: Rotten papaya pulp (250 g) were cut into small pieces and homogenized to fine paste in cold $0.1 \mathrm{M}$ sodium phosphate buffer, pH 6.0, using a mortar and pestle. The suspension was kept for $2 \mathrm{hrs}$ at $4^{\circ} \mathrm{C}$ in a refrigerator and filtered through double layer of cheese cloth. The filtrate was collected and centrifuged at $8,000 \mathrm{~g}$ for $20 \mathrm{~min}$ at $4^{\circ} \mathrm{C}$. The total volume of clear supernatant was recorded and used as crude enzyme extract. All operations were performed at $4^{\circ} \mathrm{C}$ unless otherwise indicated.

Purification of Peroxidase from Fruit Disease Infected Papaya Pulp

A mmonium sulphate fractionation: The enzyme were precipitated from the supernatant by the addition of solid $\left(\mathrm{NH}_{4}\right)_{2} \mathrm{SO}_{4}$ (90\% saturation) under constant and gentle stirring at $4^{\circ} \mathrm{C}$ and left overnight in a refrigerator. The resulting precipitate was collected by centrifugation at 8,000 $\mathrm{g}$ for $20 \mathrm{~min}$ and dissolved in a minimum volume of pre-cold Tris- $\mathrm{HCl}$ buffer, $\mathrm{pH} 8.2$ and dialyzed
L Bari1, P Hassan, N A bsar, S K hatun and MI Hossain et al overnight against $2 \times 5 \mathrm{~L}$ of distilled water at $4^{\circ} \mathrm{C}$. The dialyzed solution was then centrifuged in a refrigerated centrifuge at $8,000 \mathrm{~g}$ for $15 \mathrm{~min}$. to remove insoluble materials. The clear supernatant was used as a source of peroxidase designated as "crude enzyme solution".

DEAE-cellulose ion-exchange chromatography: The soluble enzyme extract was immediately applied to a column of DEAE-cellulose $(2.1 \mathrm{x}$ $20 \mathrm{~cm}$ ) previously equilibrated with $10 \mathrm{mM}$ Tris- $\mathrm{HCl}$ buffer, pH 8.2. After sample application, the column was washed with 10 $\mathrm{mM}$ Tris- $\mathrm{HCl}$ buffer, $\mathrm{pH} 8.2$ to wash out the unbound proteins. The column bound proteins were eluted stepwise from the column with same buffer containing different concentrations of $\mathrm{NaCl}$. The elutes from both the unbound and bound proteins were collected as $3 \mathrm{ml} /$ tube fractions on an automatic fraction collector and monitored for protein at $280 \mathrm{~nm}$ and assayed for peroxidase activity. ${ }^{18}$

Hydrophobic chromatography on phenylsepharose CL-4B: The separation using hydrophobic chromatography on Phenyl Sepharose column CL-4B was same as in the purification of peroxidase/catalase from P seudomonas aeruginosa. ${ }^{19}$

The unbound fraction from DEAE-cellulose column possessing peroxidase activity was pooled together and dialyzed against deionized water for $12 \mathrm{hrs}$ followed by dialysis against the wash buffer $(50 \mathrm{mM}$ Tris- $\mathrm{HCl}+200 \mathrm{mM}$ A mSO4, pH 7.5.) at 40 $\mathrm{C}$ for $8 \mathrm{hrs}$. A $10 \mathrm{ml}$ column containing Phenyl Sepharose CL -4B was packed and washed with 10 times the column volume with the wash buffer $(50 \mathrm{mM}$ Tris- $\mathrm{HCl}$

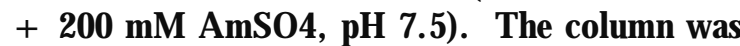
equilibrated with the equilibration buffer (50 $\mathrm{mM}$ Tris- $\mathrm{HCl}+200 \mathrm{mM} \mathrm{AmSO4,} \mathrm{pH} \mathrm{7.5).}$ After column equilibration, the enzymatically active fractions were applied to the column. The column bound proteins were eluted from the column using gradient buffer $(50 \mathrm{mM}$ Tris- $\mathrm{HCl}$, $200 \mathrm{mM} \mathrm{AmSO4}, \mathrm{pH} \mathrm{7.5)}$ and $3 \mathrm{ml}$ fractions were collected on an automatic fraction collector and monitored for protein at $280 \mathrm{~nm}$ and peroxidase activity were assayed following the method described earlier. 
Protein assay: The protein content of different fractions was measured using Bovine serum albumin (BSA) as the standard and the protein in column elute fractions was also monitored spectrophotometrically at $280 \mathrm{~nm} \cdot{ }^{20}$

\section{Test of protein homogeneity}

The homogeneity of purified protein was judged by SDS-PAGE on $7.5 \%$ gel on a Bio-Rad mini electrophoresis system. ${ }^{21}$

Characterization of Purified Protein Determination of relative molecular mass $\left(M_{r}\right)$ a) Determination of relative molecular mass $\left(M_{r}\right)$ by gel filtration: The relative molecular mass $\left(\mathrm{Mr}_{\mathrm{r}}\right)$ of purified peroxidase was determined by Gel filtration on Sephadex G-100 column $(100 \times 0.85 \mathrm{~cm})$ equilibrated with 10 $\mathrm{mM}$ Tris- $\mathrm{HCl}$ buffer, pH 8.2.22 The marker proteins used were Trypsin inhibitor (12.028 $k D)$, carbonic anhydrase (29 kD), a-amylase (58 kD), bovine serum albumin (68 kD), phosphorylase-b (97.4 kD) and e-galactosidase $(116 \mathrm{kD})$. The relative molecular mass $\left(\mathrm{M}_{\mathrm{r}}\right)$ was estimated using a plot of molecular weight versus elution volume.

b) Determination of relative molecular mass $\left(M_{r}\right)$ by SDS-PAGE: The relative molecular mass $\left(M_{r}\right)$ of purified papaya peroxidase was also determined by SDS-Polyacrylamide gel electrophoresis (SDS-PAGE) on a Bio-Rad mini electrophoresis system. ${ }^{23}$ The standard proteins used were the same as those used in determination of the relative molecular mass $\left(M_{r}\right)$ by $G$ el filtration on Sephadex G-100 column mentioned above. The gels were stained with Coomassie Brilliant Blue, CBB R-250 for 1 $\mathrm{hr}$ and destaining was performed in $7 \%$ acetic acid (v/v).

Determination of subunit structure of the purified enzyme: In order to determine subunit structure SDS-PAGE of purified enzyme under reducing and non-reducing conditions was performed. 22 Dissociation and reduction of protein was performed by heating for $5 \mathrm{~min}$ at $100^{\circ} \mathrm{C}$ in $0.1 \%$ SDS with or without $0.1 \%$ of 2-mercapto ethanol.
Carbohydrate analyses: The total neutral carbohydrate content of the purified enzyme was determined by the Phenol-Sulfuric acid method using D-glucose as the standard. ${ }^{24}$

Determination of optimum $\mathrm{pH}$ : The activity of purified enzyme was measured at different $\mathrm{pH}$ ranges $(2.0-10.0)$ at $30^{\circ} \mathrm{C}$ after incubation for 5 minutes using appropriate buffers and the residual peroxidase activity was determined as described earlier. For the purpose, the enzyme solutions $(0.5-0.6 \%)$ were dialyzed against 50 $\mathrm{mM}$ buffer of different $\mathrm{pH}$ 's $(\mathrm{pH}$ 2.0-3.0, $\mathrm{ACONa}-\mathrm{HCl}$; $\mathrm{pH}$ 4.0-5.0, $\mathrm{ACONa}-\mathrm{CH}_{3} \mathrm{COOH}$; $\mathrm{pH}$ 5.5-8.0, $\mathrm{NaH}_{2} \mathrm{PO}_{4}-\mathrm{Na}_{2} \mathrm{HPO}_{4} ; \mathrm{pH}$ 8.5-9.0, $\mathrm{Na}_{2} \mathrm{~B}_{4} \mathrm{O}_{7}-\mathrm{HCl}$; pH 9.5 and 10.0, $\mathrm{Na}_{2} \mathrm{~B}_{4} \mathrm{O}_{7^{-}}$ $\mathrm{NaCO}_{3}$ ) for $24 \mathrm{hr}$ with frequent change of buffers. A fter necessary adjustment of $\mathrm{pH}$ values by addition of $0.2 \mathrm{~N} \mathrm{HCl}$ or $0.2 \mathrm{~N} \mathrm{NaOH}$, the enzyme activities were assayed using pyrogallol as substrate at room temperature $\left(25-28^{\circ} \mathrm{C}\right)$.

Determination of optimum temperature: In order to determine optimum temperature the enzyme solutions $(0.5-0.6 \%)$ in $10 \mathrm{mM}$ sodium phosphate buffer, $\mathrm{pH}$ 7.0 were incubated at various temperatures (10$90^{\circ} \mathrm{C}$ ) for 5 minutes in a temp controlled bath. A fter cooling, the residual peroxidase activity was measured. ${ }^{18}$

Effect of salts and metal ions on peroxidase activity: Enzyme solutions (0.5\%) were dialyzed separately against deionized water at $4^{\circ} \mathrm{C}$ for 12 $\mathrm{hr}$ before incubation. The dialyzed enzyme solution $(200$ I) were added to salts solutions of different concentrations $(0.25 \mathrm{mM}-5 \mathrm{mM})$ and incubated for $1 \mathrm{hr}$ at $30^{\circ} \mathrm{C}, \mathrm{pH} 7.0$, using pyrogallol as substrate and the remaining activities were assayed at room temperature.

Determination of $\mathrm{Km}$ value: The apparent $M$ ichaelis constant $(\mathrm{Km})$ was determined from Lineweaver-Burk double reciprocal plot using pyrogallol as substrate 25 . The initial velocity is equal to the amount of product formed per unit time. The initial velocity $\left(V_{0}\right)$ was determined by measuring quantitatively the amount of one of the products at various time intervals. 
Results

\section{Protein purification}

Peroxidases from rotten papaya were purified by ammonium sulphate precipitation of crude extract, chromatography on DEAE-cellulose followed by hydrophobic chromatography on Phenyl Sepharose CL -4B.

DEAE-cellulose chromatography: The $90 \%$ $\left(\mathrm{NH}_{4}\right)_{2} \mathrm{SO}_{4}$ saturated crude enzyme extract was applied to a DEAE-cellulose column at $4^{\circ} \mathrm{C}$, equilibrated with $10 \mathrm{mM}$ Tris- $\mathrm{HCl}$ buffer, $\mathrm{pH} 8.2$. After sample application, the column was washed with $10 \mathrm{mM}$ Tris- $\mathrm{HCl}$ buffer, $\mathrm{pH} 8.2$ to elute the unbound protein fractions. The column bound proteins were eluted from the column by stepwise elution with the buffer containing increasing concentration of $\mathrm{NaCl}$. As shown in Fig. 1, the proteins were eluted from the column as three fractions. The fraction, F-1 was eluted from the column by the buffer only, while the other two fractions i.e. F-2 and F-3 were eluted with $10 \mathrm{mM}$ Tris- $\mathrm{HCl}$ buffer, $\mathrm{pH} 8.2$ containing $0.5 \mathrm{M}$ and 1.0 $\mathrm{M} \mathrm{NaCl}$, respectively. Only the $\mathrm{F}-1$ fraction exhibited peroxidase activity while the other two fractions i.e. F-2 and F-3, did not show any peroxidase activity and were not included in further study. The fractions of F-1, as indicated by solid bar, were pooled and its homogenity was checked by polyacrylamide disc gel electrophoresis. The F-1 fraction produced more than one band on the gel, indicating that it contained impure peroxidase enzyme. Therefore, for further purification, this fraction was subjected to hydrophobic chromatography on Phenyl Sepharose CL-4B.

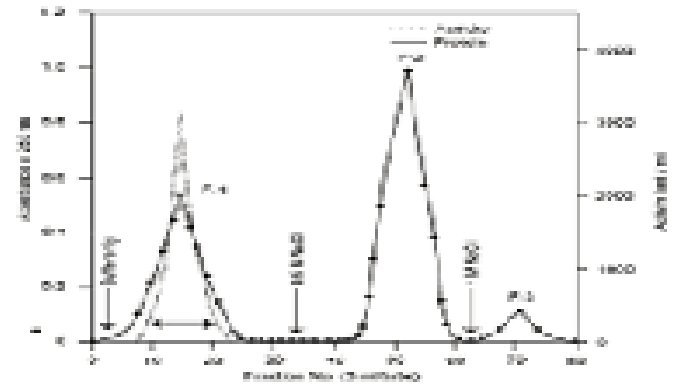

Fig. 1. Ion-exchange chromatography of crude cell extract on DEAE-cellulose. The crude extract solution (42 mg) was applied to the column $(2.1 \times 20 \mathrm{~cm})$ pre-equilibrated with 10 $\mathrm{mM}$ Tris- $\mathrm{HCl}$ buffer, $\mathrm{pH} 8.2$ at $4 \mathrm{C}$ and eluted by stepwise increase of $\mathrm{NaCl}$ concentrations in the same buffer. Flow rate: $45 \mathrm{ml} / \mathrm{hr}$.
L Bari1, P Hassan, N A bsar, S K hatun and M I Hossain et al Phenyl-sepharose CL -4B chromatography: The enzymatically active fraction of $F-1$, obtained from DEAE-cellulose chromatography was dialyzed against wash buffer, $50 \mathrm{mM}$ Tris- $\mathrm{HCl}$ $+200 \mathrm{mM} \mathrm{AmSO}_{4}, \mathrm{pH} 7.5$ for 6-7 hours and applied to a Phenyl Sepharose CL-4B column, equilibrated with the same buffer at $4^{\circ} \mathrm{C}$. As shown in Fig.2, the unbound small protein fraction from Phenyl Sepharose CL -4B column designated as F-1a was collected and monitored for enzyme activity. This fraction exhibited no peroxidase activity and so it was discarded.

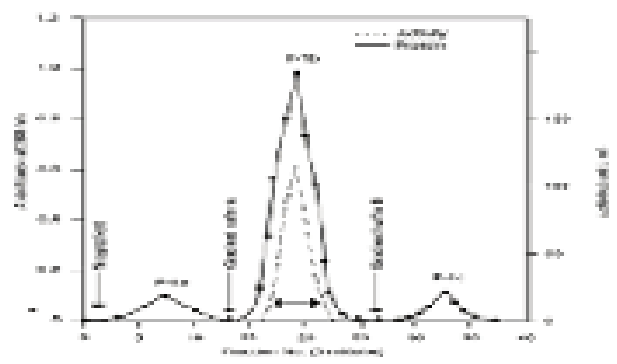

Fig. 2. Hydrophobic Chromatography of F-1 fraction (from DEAE cellulose) on Phenyl Sepharose CL-4B column. The pooled fraction of F-1 from DEAE cellulose chromatography $(25 \mathrm{ml})$ was applied to the column (1 $\times 10 \mathrm{~cm}$ ) pre-equilibrated with wash buffer, $50 \mathrm{mM}$ Tris- $\mathrm{HCl}+200 \mathrm{mM}$ A mSO4, pH 7.5 at $4 \mathrm{C}$ and eluted with gradient buffer $\mathrm{A}(50 \mathrm{mM}$ Tris- $\mathrm{HCl}$ $+200 \mathrm{mM} \mathrm{AmS04}, \mathrm{pH} 7.5)$ and gradient buffer B (50 mM Tris- $\mathrm{HCl}, \mathrm{pH} 7.5)$ stepwisely. Flow rate: $25 \mathrm{ml} /$ hour.

On the other hand, the major fraction F-1b, as represented in Fig. 3, was found to be eluted with gradient buffer A $(50 \mathrm{mM}$ Tris- $\mathrm{HCl}+200 \mathrm{mM}$ $\mathrm{AmSO}_{4}, \mathrm{pH}$ 7.5) while the fraction $\mathrm{F}-1 \mathrm{c}$ was eluted with gradient buffer $\mathrm{B}(50 \mathrm{mM}$ Tris- $\mathrm{HCl}$, $\mathrm{pH} \mathrm{7.5).} \mathrm{Of} \mathrm{these} \mathrm{two} \mathrm{fractions,} \mathrm{it} \mathrm{was} \mathrm{found} \mathrm{that}$ only F-1b exhibited major peroxidase activity but F-1C also contained slight peroxidase activity.

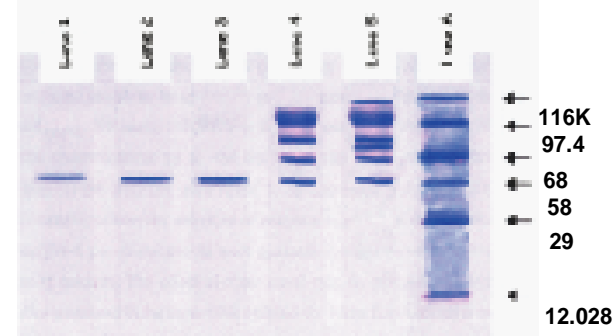

Fig. 3. Photograph of SDS-Polyacrylamide slab gel electrophoresis of various fractions obtained during the purification of Peroxidase and the marker protein. Lane 1 = Purified papaya peroxidase from Phenyl Sepharose CL-4B column (under reducing condition). Lane 2 and lane $3=$ Purified papaya peroxidase from Phenyl Sepharose CL $-4 B$ column (under non-reducing condition), Lane $4=$ Unbound fraction from DEAE-cellulose column., $L$ ane $5=$ Crude enzyme extract and $L$ ane 6 $=$ M arker proteins. 
Purification and Characterization of Peroxidase from A nthracnose As shown in Fig. 2, F-1b fraction having significant peroxidase activity, as indicated by solid bar, was pooled and its purity was judged on SDS-PAGE. This fraction might contain pure protein i.e. peroxidase enzyme, as it gave a single band on the gel (Fig. 3). The data pertaining to the purification of peroxidase from rotten papaya has been summarized in Table 1 .

Table 1: Summary on the purification of Papaya peroxidase.

\begin{tabular}{|c|c|c|c|c|c|c|}
\hline Steps & $\begin{array}{l}\text { Volume } \\
\text { (ml) }\end{array}$ & $\begin{array}{l}\text { Total } \\
\text { protein } \\
(\mathrm{mg})\end{array}$ & $\begin{array}{l}\text { Total } \\
\text { activity } \\
\text { (Units) } \\
\end{array}$ & $\begin{array}{l}\text { Specific } \\
\text { activity } \\
\text { (Unit/mg) }\end{array}$ & $\begin{array}{l}\text { Recovery } \\
(\%)\end{array}$ & $\begin{array}{l}\text { Purification } \\
\text { folds }\end{array}$ \\
\hline $\begin{array}{l}\text { Crude extract } \\
\mathrm{AmSO}_{4} \\
\text { fractionation } \\
90 \%\end{array}$ & $\begin{array}{l}300 \\
250\end{array}$ & $\begin{array}{l}348 \\
266\end{array}$ & $\begin{array}{l}4756 \\
4590\end{array}$ & $\begin{array}{l}13.66 \\
17.25\end{array}$ & $\begin{array}{l}100 \\
96.5\end{array}$ & $\begin{array}{c}1 \\
1.26\end{array}$ \\
\hline $\begin{array}{l}\text { DEAE - cellulose } \\
\text { column }\end{array}$ & se 10 & 82 & 3229.2 & 39.38 & 67.89 & 3.5 \\
\hline $\begin{array}{l}\text { Phenyl Sepharose } \\
\text { column }\end{array}$ & se 25 & 3.5 & 118.9 & 33.97 & 2.5 & 7.2 \\
\hline
\end{tabular}

As shown in table specific activity of peroxidase was increased at each purification steps. Although the yield/recovery was about $2.5 \%$ but the enzyme activity was increased more than seven folds.

\section{Characterization of Purified Protein}

M olecular weight determination by gel filtration method: The relative molecular mass ( $\mathrm{Mr}$ ) of the purified peroxidase enzyme from rotten papaya fruit pulp was determined by gel filtration on a Sephadex G-100 column and it was determined using a plot of molecular weight versus elution volume (Fig. 4) and was calculated to be about 55,000 .

Determination of relative molecular mass ( $\mathrm{Mr}$ ) by SDS-PAGE: The relative molecular mass $(\mathrm{Mr})$ of purified papaya peroxidase was also determined by SDS-Polyacrylamide slab gel electrophoresis on a Bio-Rad mini electrophoresis system. ${ }^{23}$ The standard curve of marker proteins was constructed by plotting log of the relative molecular mass of the proteins against their mobility on the gel (Fig. 5).

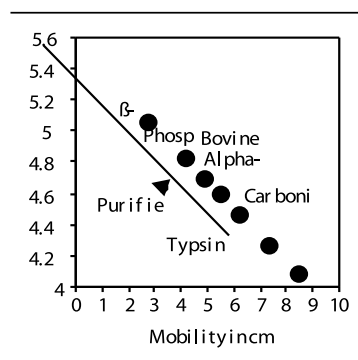

Fig. 4. Standard curve for the determination of relative molecular mass of peroxidase by gel filtration method.

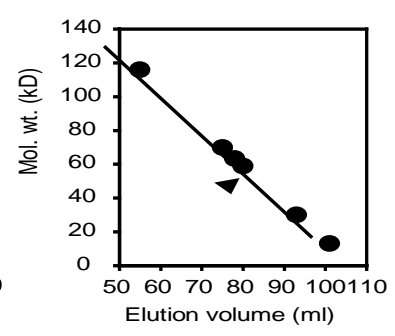

Fig. 5. Standard curve for the determination of relative molecular mass of peroxidase by SDS-PAGE method.

The relative molecular mass of rotten papaya peroxidase was determined to be 50000 . A wide range of $\mathrm{Mr}_{\mathrm{r}} \mathrm{s}$ (3000 to 60000) has been reported for peroxidase from various sources. ${ }^{26}$ Thus, the relative molecular mass of peroxidase from rotten papaya pulp obtained in this study is in general agreement with those reported in the literature.

Neutral sugar content of peroxidase: The purified enzyme gave yellow-orange color in the presence of Phenol-Sulfuric acid indicating that the enzyme contains sugar. The neutral sugar content of papaya peroxidase was calculated from a standard curve of glucose (Figure, not shown) and it was found to be about $15 \%$.

\section{Effect of pH on enzyme activity}

The activity of purified enzyme was measured at different $\mathrm{pH}$ ranges $(2.0-10.0)$ at $30^{\circ} \mathrm{C}$. Peroxidase activity as a function of $\mathrm{pH}$ using pyrogallol as substrate showed a broad $\mathrm{pH}$ profile throughout the $\mathrm{pH}$ 5- 6.5 ranges. The optimum $\mathrm{pH}$ was $\mathrm{pH} 6.0$, with the activity falling off slowly above this value and reaching half the maximum level at $\mathrm{pH} 8.8$ or approximately 9.0 .

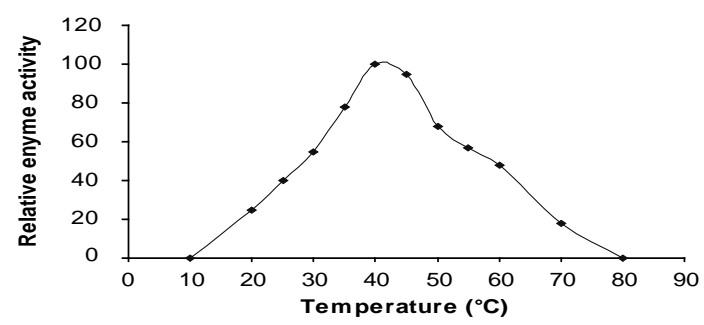

Fig. 6. Effect of pH on papaya peroxidase activity

In contrast, a sharp decrease in activity was observed as the pH was lowered below 5.0. The 
$\mathrm{pH}$ stability study showed that the enzyme lost no activity when held for $1 \mathrm{hr}$ at $30^{\circ} \mathrm{C}$ and $\mathrm{pH}$ 6.0 , whereas on the more acid side below the optimum there was a marked decrease in stability with a total loss of activity at pH 3.0.

\section{E ffect of temperature on enzyme activity}

The effect of temperature on the activity of the purified enzyme from rotten papaya pulp of local-1 variety was examined at $30^{\circ} \mathrm{C}$ after 5 min incubation in $10 \mathrm{mM}$ sodium phosphate buffer, $\mathrm{pH}-6.0$ at various temperatures $\left(10-90^{\circ} \mathrm{C}\right)$ in a temp controlled bath and the residual activity was measured after cooling at room temperature $\left(25-28^{\circ} \mathrm{C}\right)$.

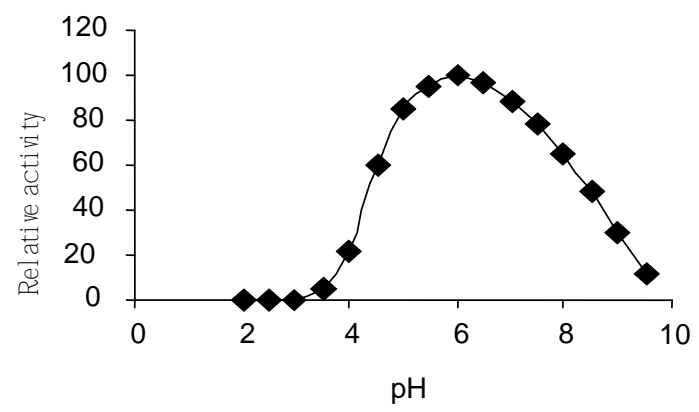

Fig. 7. Effect of temperature on papaya peroxidase.

As shown in Figure 7, the activity of purified papaya peroxidase was found to be affected profoundly by changes of temperature. The activity increased gradually and around $25^{\circ} \mathrm{C}$ the enzyme activity was observed only about $40 \%$. A sharp increase in enzyme activity was noticed when the temperature reached around $30^{\circ} \mathrm{C}$ and the enzyme showed the maximum activity around $38^{\circ} \mathrm{C}$. The enzyme activity was found to be decreased gradually with further rise of temperature and the activity was lost sharply above $50^{\circ} \mathrm{C}$. Only $18 \%$ of the original activity was remained at $70^{\circ} \mathrm{C}$, while at $80^{\circ} \mathrm{C}$ the activity was lost completely (Fig. 7).

On the other hand, the enzyme was incubated at different temperatures at $\mathrm{pH} 6.0$ for $60 \mathrm{~min}$. and the residual activity was measured after cooling at room temperature $\left(25-28^{\circ} \mathrm{C}\right)$. The enzyme was found to be stable within the ranges of 30 $55^{\circ} \mathrm{C}$ and was found to be very much stable when incubated at $35^{\circ} \mathrm{C}$.
E ffect of salts, metal ions and SH-blocking reagents on peroxidase activity

The effect of several compounds on peroxidase activity was tested. An adhoc experiment was first conducted to have an idea about the possible inhibitory or activatory effects of added compounds on peroxidase activity. To do so, substances were added to peroxidase enzymes in various concentrations ranging from $0.25 \mathrm{mM}$ to $5 \mathrm{mM}$ and incubating the enzymes for $1 \mathrm{hr}$ at $30^{\circ} \mathrm{C}$ and the remaining peroxidase activity assayed. However, the precise results have been presented in Table 2 .

Table 2. Effects of various ions and chemicals on the activity of Papaya peroxidase

\begin{tabular}{lccc}
\hline \multicolumn{1}{c}{ Reagents added } & $(\mathrm{mM})$ & $\begin{array}{c}\text { Relative Activity } \\
(\%)\end{array}$ & Remarks \\
\hline None & 1 & 100 \\
p-Chloromercuribenzoate & & 89 \\
(PCMB) & 2.5 & 80 \\
lodoacetate & 0.5 & 92 \\
$\mathrm{~N}$-ethylmaleimide & 1 & 1 \\
$\mathrm{FeSO}_{4}$ & 1 & 3.5 \\
$\mathrm{KCN}_{\mathrm{CuSO}}$ & 1 & 99 \\
$\mathrm{MgCl}_{2}$ & 1 & 98 \\
$\mathrm{MnCl}_{2}$ & 1 & 96 \\
$\mathrm{CaCl}_{2}$ & 1 & 99 \\
$\mathrm{ZnSO}_{4}$ & 1 & 100 \\
$\mathrm{Amm}^{\mathrm{SO}_{4}}$ & 1 & 145 \\
\hline
\end{tabular}

As shown in Table 2, the thiol reagents $p$ chloromercuribenzoate, iodoacetate and $\mathrm{N}$ ethylmaleimide practically were not effective inhibitors of peroxidases as its activity was not lost significantly in their presence and only 8 to $20 \%$ loss in enzyme activity was observed. The peroxidase activity was found to be almost completely lost in the presence of $\mathrm{Fe}^{2+}$ and $\mathrm{KCN}$ (Table 2). Therefore, they appeared to be the best inhibitors of peroxidase. The following cations had no effect on the activity of enzyme: $\mathrm{Zn}^{++}$, $\mathrm{Ca}^{++}, \mathrm{Cu}^{++}, \mathrm{Mg}^{++}$and $\mathrm{Mn}^{++}$. (Table 2). Very interestingly, the activity of papaya peroxidase was found to be activated remarkably $(145 \%)$ in the presence of ammonium sulfate. 
Purification and Characterization of Peroxidase from Anthracnose

\section{Determination of $\mathrm{K} \mathbf{m}$ value}

The activity of purified enzyme was analyzed using different concentrations of pyrogallol as substrate. The $\mathrm{Km}$ value for peroxidase purified from rotten papaya pulp was calculated to be $0.027 \mathrm{mM}$ (Fig. 8).

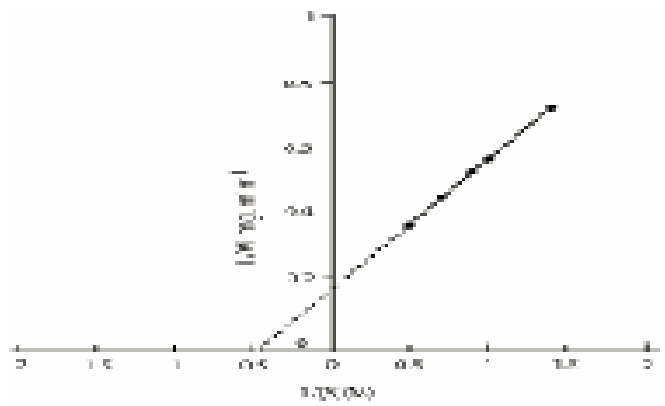

Fig. 8. Lineweaver-Burk double reciprocal plots for the determination of $\mathrm{Km}$ value of purified peroxidase.

\section{Discussion}

Peroxidases from different sources such as tomato 26 , peach fruit 27 , carrot roots ${ }^{3}$, potato 28 and opuntia ${ }^{1}$ have been purified and characterized.

In the present study a peroxidase enzyme from the crude extract of papaya pulp of local variety infected with the fungi Colletotrichum gloeosporioides was purified by ammonium sulphate precipitation of crude extract, chromatography on DEAE-cellulose followed by hydrophobic chromatography on Phenyl Sepharose CL-4B.

The relative molecular mass $\left(M_{r}\right)$ of peroxidase from papaya pulp was calculated to be approximately $55 \mathrm{kD}$ and $50 \mathrm{kD}$ by gel filtration on Sephadex G-100 and SDS-polyacrylamide gel electrophoresis, respectively. Almost similar relative molecular mass ( $\mathrm{Mr}$ ) of bound peroxidases have been purified from papaya fruit in Brazil ${ }^{29}$. A wide range of relative molecular masses, $M$ rs (30-60) kD has been reported for peroxidases from various sources. A nionic peroxidases have been purified from potato having a molecular mass of $45-\mathrm{KD}^{26}$. Ionically bound peroxidases have been isolated and purified from peach fruit having molecular weight 29-kD by DEAE-cellulose and Sephadex G-100 chromatography. ${ }^{30}$
In our study, although the enzyme was purified with an increase of purification fold of about 7 but the yield was found to be about $2.5 \%$ only. This decrease in yield may be due to denaturation of enzyme during the lengthy purification procedures or for some other unknown reasons. It was reported that $28 \%$ yield of peroxidase from papaya fruit 29 and about $19.8 \%$ from potato. ${ }^{28}$

The molecular mass of our purified papaya peroxidase was found to be the same under both reducing and non-reducing conditions indicating that the enzyme has no sub-unit structure. The purified enzyme from papaya is glycoprotein in nature. It was reported that grapevine peroxidases are glycoprotein. ${ }^{2}$ In our study, the neutral sugar content of papaya peroxidase was found to be about $15 \%$. It has been showed that horse raddish peroxidase is also a glycoprotein and contain about $18 \%$ carbohydrate. ${ }^{31}$

The optimum $\mathrm{pH}$ of our purified papaya peroxidase was calculated to be around 6.0 (Fig. 5.3.). Very similar pattern of $\mathrm{pH}$ profiles for peroxidase in potato was reported. ${ }^{28}$ It has been reported that the optimum $\mathrm{pH}$ for peach fruit peroxidase to be 5.0 .27 The optimum pH of 5.75 for O puntia peroxidase have been also reported. ${ }^{1}$

Our purified peroxidase from papaya was found to be stable at $\mathrm{pH}$ values between 5.0 to 6.5 . This result clearly demonstrated that papaya pulp peroxidase was more stable in acidic $\mathrm{pH}$ region. The results agree very well with the similar $\mathrm{pH}$ stability for peroxidase from blackberry fruits. ${ }^{29}$

The study on the effect of different temperatures on the activity of peroxidase revealed that the activity of purified papaya peroxidase was found to be affected profoundly by changes of temperature. The activity increased gradually and a sharp increase in enzyme activity was observed when the temperature reached $30^{\circ} \mathrm{C}$ and the optimum temperature was around $38^{\circ} \mathrm{C}$ (Fig. 5.4). Further increase of temperature caused decrease in enzyme activity probably because of enzyme denaturation.

Study on peroxidase from peach fruit demonstrated optimum activity at $40^{\circ} \mathrm{C} .{ }^{27}$ It was reported that the optimum temperature of carrot root peroxidase to be $32^{\circ} \mathrm{C}^{4}$ while the optimum temperature for 
Cantloupe melon peroxidase around $50-55^{\circ} \mathrm{C} .32 \mathrm{The}$ peroxidase enzyme purified from papaya by us was found to be stable between $30^{\circ} \mathrm{C}$ to $55^{\circ} \mathrm{C}$. Peach peroxidase showed very similar temperature stability. ${ }^{30}$ This fact was also observed in case of isolated enzymes from apple ${ }^{13}$ and orange. ${ }^{10}$

It is worth noting that the inhibitors had different effects on papaya peroxidase purified in our study. The following cations such as $\mathrm{Zn}^{++}, \mathrm{Cu}^{++}, \mathrm{Ca}{ }^{++}, \mathrm{Mg}^{++}$and $\mathrm{Mn}^{++}$, had no effect on the enzyme activity. A similar non inhibitory effect of the above ions in case of papaya peroxidase ${ }^{29}$ was observed. However, $\mathrm{Fe}^{++}$and $\mathrm{KCN}$ were found to have pronounced inhibitory effect on the activity of the peroxidase. Similar inhibitory effects of $\mathrm{Fe}^{++}$ and $\mathrm{KCN}$ was also reported earlier. ${ }^{27}$

Very interestingly, the activity of papaya peroxidase was found to be activated remarkably $(145 \%)$ in the presence of ammonium sulfate. Remarkable activation of horse raddish peroxidase was also observed in the presence of ammonium sulfate. ${ }^{31}$

The sulfhydryl inhibitors p-chloromercuribenzoate, iodacetate and $\mathrm{N}$-ethylmaleimide practically were not effective inhibitors, indicating that (-SH) groups may not be involved in peroxidase catalysis. Different workers have found the non-essentiality of $(-\mathrm{SH})$ groups for catalysis in Peroxidases of distinct sources. 30

The kinetic constant $\mathrm{Km}$ for papaya peroxidase against pyrogallol as substrate was estimated to be $0.027 \mathrm{mM}$. It was reported that the $\mathrm{Km}$ values with o-dianasidine, guaiacol and $\mathrm{p}$ phenylenediamine as substrate to be $0.16,0.2$ and $0.1 \mathrm{mM}$ respectively for bound papaya peroxidase. ${ }^{29}$ It was also found that the $\mathrm{Km}$ value of 9.35 and $15.38 \mathrm{mM}$ using o-dianisidine and hydrogen peroxide respectively as substrate for peach peroxidase. 27

The present study revealed that the ripe papaya pulp infected by Colletotrichum gloeosporioides, is a rich source of peroxidase having high $\mathrm{pH}$ stability and thermostability, so might be considered for use industrially by large scale production.
L Bari1, P Hassan, N A bsar, S K hatun and M I Hossain et al

\section{References}

1. Alessandra Padiglia, Elena Cruciani, Giuliana Pazzaglia, Rosaria Medda and Giovanni. Floris Purification and characterization of Opuntia peroxidase. Phytochemistry 1995; 38: 295-297.

2. Alfonso Ros Bercelo, Federico Pomar, Matlas Lopez Serrano and $M$ aria Angeles Pedreno. Peroxidase : a multifunctional enzyme in grapevines, Functional Plant Biology 2003; 30(6): 577-591.

3. Ayyappan, R. Nair, and Allan, M. Showalter. Purification and Characterization of a WoundInducible Cell Wall Cationic Peroxidas from Carrot Roots. Biochemical and Biophysi cal Research Communication 1996; 226: 254-260.

4. A beles, F. B. and Biles, C. L. Characterization of peroxidase in lignifying peach fruit endocarp. Plant physiology 1991; 95: 269-273.

5. Gillikin, J. W. and Graham, J. S. Purification and developmental analysis of the major anionic peroxidase from the seed coat of Glycin max. Plant Physiology 1991; 96: 214-220.

6. Haard, N. F. Physiological roles of peroxidase in postharvest fruits and vegetables. In-Enzymes in food and beverages processing, eds. Ory, R.L. \& St. Angelo, A. J. ACS 1977; 143.

7. Hammerschmidt, R., Lamport, D. T. A. and Muldoon, E. P. Cell wall hydroxylproline enhancement and lignin deposition as an early event in the resistance of cucumber to Cladosporium cucumerium. Physiol, Plant Pathol 1984; 24: 43-47.

8. Burnette, F. S. Peroxidase and its relation to food flavor and quality. A review. J. Food Sci 1977; 4: 1-6.

9. Clemente, E. Isolamento, purificacao e termoestabilidade da isoperoxidase do suco de Iaranja. Cienc. Tecnol. A liment 1996; 16: 1-5.

10. Haard, N. F. U psurge of particulate peroxidase in ripening banana fruit. Phytochemistry 1973.

11. 555-560.12. M oulding P H, Goodfellow J, M CL ellan $K M$ and Robinson $D S$. The occurrence of isoperoxidases in conference pears. Int. J. Food Sci. Technol 1989; 24: 269-275.

12. Moulding $P H, G$ rant $H F, M C L$ ellan $K M$ and Robinson D S. Heat stability of soluble and ionically bound peroxidases extracted from apples. Int. .J. Food Sci. Technol 1987; 22: 391-397. 
13. Robinson D S, Bretheric R and Donnelly J. The heat stability and isoenzyme composition of peroxidase in Ohane grapes. Int. J. Food Sci. Technol 1989; 24: 613-618.

14. Wang $Z$ and Luh B S. Characterization of soluble and bound peroxidase in green asparagus. J. Food Sci 1983; 48: 1412-21.

15. Nord F F. Advances in enzymology and related subjects of biochemistry. Interscience Pub 1953; 15: 156-158.

16. Kemeny, D. M. and Challacombe, S. J. ELISA and other solid phase immunoassays. John Wiley and sons. USA. 1989; 1-16.

17. Zia $M A, Y$ aqub $M$, Rehman $K$ and $M$ ahmood $T$. Production of rabbit antibuffalo antibodies horseradish peroxidase conjugate and standardization of ELISA for Pasteurella multocida antibodies. Pak. J. Biol. Sci 2000; 3: 1716-1718.

18. Mahadevan A and Sridahar R. Methods of physiological plant pathology (2nd Ed.) Sivakasi Publications 1982; M adras, India.

19. Marcia A. Miller-Rodeberg (2004) Purification of peroxidase/catalase from Pseudomonas aeruginosa. In: Laboratory Procedure, (chemistry 455, group-2) University of W isconsin Eau Claire, U nited States of A merica.URL: thttp:// www. uwec. edu /millerra/ myweb/chem455/group2. doc

20. Lowry, O. H., Farr, N. and Randell, R. J. Protein measurement with the Folin-phenol reagent. J. Biol. Chem 1951; 193: 265-275.

21. Lammli, U. K. Cleavage of structural proteins during the assembly of the head of bacteriophage T4. Nature 1970; 227: 680.

22. Andrews, P. The gel filtration- Behavior of protein related to their molecular weights over a wide range. Biochem. J 1965; 96: 596-605.
23. Dubois, M., Gilles, K., Hamilton, J. K., Rebers, P. A. and Smith, F. A colorimetric method for the determination of sugars and related substances. A nal. Chem 1956; 28: 350-356.

24. Robyt J F and White B J (1990) Biochemical techniques: theory and practice. Waveland Press Inc., Illinois, USA, 295-296, 304-305.

25. Srivastava $0 \mathrm{~m} P$ and Huystee $R B$ van. Spectral and molecular properties of peanut peroxidase isozymes. Phytochemistry 1977; 16: 1657-1659.

26. Kokkinakis, D. M. and Brooks, J. L. Tomato peroxidase: purification, characterization and catalytic properties. Plant Physiol 1979; 63: 93-99.

27. Valdir Augusto Neves. Ionically Bound Peroxidase from Peach Fruit. Brazilian Archives of Biology and Technology 2002; 45: 7-16.

28. Mark A Bernards, Warren D Fleming, David B Liewellyn, Ronny Priefer, Xiaolong $Y$ ang, A nita Sabatino and Guy L Plourde. Biochemical Characterization of the Suberization-Associated Anionic Peroxidase of Potato. Plant Physiology 1999; 121: 135-145.

29. Silva $E$, Lourenco $E J$ and $N$ eves $\vee A$. Soluble and bound peroxidase from papaya fruit. Phytochemistry 1990; 29: 1051-1056.

30. Neves $V A$ and Lourenco $E J$ Peroxidase from peach fruit: Thermal stability. Braz. Arch. Biol. Technol 1998; 41(2): 179-186.

31. Fridovich, I. The stimulation of horseradish peroxidase by nitrogenous ligands. J. Biol. Chem 1963; 238: 3921-3927.

32. Lamikanra, O. and Watson, M. A. Cantaloupe melon peroxidase: Characterization and effects of additives on activity. Wiley Inter Science J 2000; 44: 168-172. 